умений моделировать решение социально-педагогических ситуаций - на 25 \%. Результаты повторного анкетирования показали, что у студентов повысился не только интерес к работе с данной категорией детей, а также и знания особенностей и проблем их социализации. Важно отметить и то, что студенты научились анализировать проблемные ситуации, возникающие в среде, где учится одаренный школьник. Повышение качества знаний студентов в этом направлении, развитие практических умений способствовало улучшению показателей их мотивации к социально-педагогическому сопровождению одаренных школьников.

Таким образом, необходимыми условиями эффективной подготовки будущих социальных педагогов к социально-педагогическому сопровождению одаренных школьников является не только формирование их готовности к решению социальнопедагогических ситуаций, а также развитие их личностных и профессиональных качеств, коммуникативных и организаторских умений, интереса к работе с одаренными детьми, но и своевременная их диагностика, адекватно выбранные ее методы и средства для повышения готовности социальных педагогов к качественному сопровождению участников учебновоспитательного процесса. Использование педагогического тестирования, психологических стандартизированных методик в процессе подготовки социальных педагогов, прошедших экспертизу, проверенных на валидность и надежность, помогает выявить глубину знаний социальных педагогов, уровень общей осведомленности о профессии социального педагога, а также уровень знаний и сформированность умений, необходимых для работы с одаренными детьми.

\title{
Литература
}

1. Карпова С. И. Проблема детской одаренности на современном этапе развития отечественного образования: [монографія] / $\quad$ С. И. Карпова. - Одинцово : АНОО «Одинцовский гуманитарный университет», 2008. - 151 с. 2. Модель социального сопровождения интеллектуально одаренных детей в области физики и математики, обеспечивающая им необходимую академическую мобильность / М. А. Червонный, Т. В. Швалева, А. А. Власова, Е. И. Цвенгер // Вестник ТГПУ (TSPU Bullutin). - 2012. - № 7 (122). - С. 250. 3. Яковенко К. Ю. Методичні рекомендації зі спецкурсу «Організація соціально-педагогічного супроводу обдарованих школярів» за вимогами кредитно-модульної системи для студентів денної та заочної форм навчання спеціальності «Соціальна педагогіка» / К. Ю. Яковенко. - Харків : ХНПУ, 2011. - 68 с. 4. Яковенко К. Ю. Методичні матеріали тренінгу «Практичні аспекти підготовки соціального педагога до роботи 3 обдарованими дітьми» / К. Ю. Яковенко. - Харків : ХНПУ, 2010. - 36 с. 5. Ярошенко О. Г. Диагностика профессионально-практической подготовки студентов профессий «человекчеловек» с использованием квалиметрии // Международный журнал экспериментального образования. - 2013. - № 4 - С. 342-344.

УДК $371.13: 372.4$

Наталія Борисенко, Наталія Сидоренко

\section{МОДЕЛЮВАННЯ САМООСВІТНЬОЇ ДІЯЛЬНОСТІ МАЙБУТНЬОГО ВЧИТЕЛЯ ПОЧАТКОВОЇ ШКОЛИ: ДІАГНОСТИЧНИЙ АСПЕКТ}

Борисенко Н. М., Сидоренко Н. І. Моделювання самоосвітньої діяльності майбутнього вчителя початкової школи: діагностичний аспект.

У статті проаналізовано можливості комп'ютерної діагностики самоосвітньої діяльності майбутнього вчителя початкової школи в межах синергетичного підходу, 
визначено основні принципи, етапи та умови моделювання елементів діагностичного процесу.

Ключові слова: діагностика, самоосвітня діяльність майбутнього вчителя початкової школи, синергетичний підхід, моделювання педагогічних процесів.

Борисенко Н. М., Сидоренко Н. И. Моделирование самообразовательной деятельности будущого учителя начальной школы: диагностический аспект.

В статье проанализированы возможности компьютерной диагностики самообразовательной деятельности будущего учителя начальных классов в рамках синергетического подхода, обозначены основные принципы, этапы и условия моделирования элементов диагностического процесса.

Ключевые слова: диагностика, самообразовательная деятельность будущего учителя начальной школы, синергетический подход, моделирование педагогических процессов.

Borisenko N. M., Sydorenko N. I. Modeling of self-educational activity of future primary school teacher: the diagnostic aspect.

In the article possibilities of computer diagnostics of self-educational activity of future primary school teacher within the synergetic approach are analyzed, the basic peinciples, stages and conditions of modeling of diagnostic process elements are defined.

Key words: diagnostics, self-education of future primary school teachers, teaching skills, synergetic approach, modeling of diagnostic processes.

Перебудова структури і змісту вищої професійної освіти зумовила необхідність розв'язання низки проблем, пов'язаних з удосконаленням процесу методичного супроводу фахової підготовки майбутнього вчителя початкової школи.

Відповідно до нормативних документів галузевого стандарту вищої освіти основними принципами фахової підготовки є такі: цілеспрямованість, прогностичність, технологічність, діагностичність. Це дає підстави визначати теоретико-методологічну базу самоосвітньої діяльності майбутнього вчителя та їі ефективної діагностики з урахуванням необхідності використання компетентнісної парадигми освіти в межах синергетичного підходу.

Мета статmі полягає у визначенні моделі процесу діагностики самоосвітньої діяльності майбутніх учителів початкової школи.

Проблема формування самоосвітніх компетенцій майбутнього вчителя, як зазначає I. Шапошнікова, стала останнім часом все більше виходити на загальнодидактичний, загальнопедагогічний і методологічний рівні і потребує проведення спеціальних досліджень, пов'язаних із визначенням нових підходів до структурування змісту підготовки вчителя, осучаснення технологічного забезпечення процесу навчання, зміни особистісного бачення викладачами і студентами необхідності інтерактивної взаємодії як запоруки підвищення якості освіти.

Грунтуючись на дослідженнях психологів i педагогів (В. Бондаря, І. Зязюна, Н. Кузьміної, А. Маркової, М. Фіцули, Л. Хоружої), що у різні роки розробляли теоретикометодологічні і технологічні засади формування дидактичних умінь різного ієрархічного підпорядкування, ми ставили за мету з'ясувати умови успішної діагностики самоосвітньої діяльності майбутнього вчителя початкової школи. Наш інтерес до синергетичного підходу як стратегії управління складними системними об'єктами був зумовлений пошуком відповіді на питання: як забезпечити умови резонансного впливу на систему методичної підготовки 
майбутніх учителів початкових класів. Діагностичні процедури дають, як правило, можливість перевірити якість засвоєння комплексних дидактичних умін. Контрольні зрізи, зазвичай, фіксують певні утруднення студентів у дидактичному поясненні методичних варіантів прояву таких процесів, як: конструювання методів навчання відповідно до заданих умов, визначення ланок процесу засвоєння знань у структурі методичного змісту уроку, здійснення цілепокладання $\mathrm{i}$ цілезабезпечення на кожному 3 методичних етапів відпрацювання змісту навчального матеріалу.

Так, у роботі С. Кульневич [5] розкрито особливості синергетичної концепції самоорганізуючого навчання, В. Маткін досліджував особливості ціннісно-синергетичного підходу в процесі педагогічної підготовки майбутніх учителів [6]. На нашу думку, для ефективного формування навичок самоосвітньої діяльності майбутніх педагогів необхідно звернути увагу на активне використання інноваційних технологій навчання. Звичайно, процес формування компетентності $є$ досить індивідуальним для кожного студента i зумовлений багатьма суб'єктивними чинниками. Водночас упровадження нових стандартів вищої професійної освіти потребує і від викладачів зміни власних стереотипів у викладацькій діяльності.

Моделювання педагогічних систем $є$ одним 3 найважливіших завдань сучасної педагогіки i психології. Завдяки моделюванню можна відтворити не лише статику дидактичного процесу, а і його динаміку. Під моделюванням розуміють не тільки процес побудови, але й дослідження моделей. Наявність науково обгрунтованої моделі навчального процесу дозволяє прогнозувати його розвиток. А це особливо важливо для освітнього процесу, бо в ньому обов'язково слід передбачати й прогнозувати майбутній позитивний результат.

У педагогічній науці метод моделювання досліджувався у працях В. Афанасьєва, В. Веникова, Б. Глинського, І. Новик, Г. Суходольского, В. Штоффа й ін. Науковцями встановлено, що педагогічне моделювання засноване на системі принципів. Дослідниця О .Чуб [9] до їх складу відносить:

1. Принциип особистісних пріоритетів припускає центрування уваги на особистісних властивостях студента, схильностях, здатностях, пріоритетах, цінностях. Побудова моделі педагогічного процесу, в першу чергу, базується на принципах гуманізації, демократизації, природовідповідності й ін.

2. Принции саморозвитку спрямований на створення таких педагогічних моделей, які відрізнялися б динамічністю, могли варіюватися залежно від конкретної навчально-виховної та соціальної ситуації.

3. Принции реальності означає відтворюваність розробленої педагогічної моделі на практиці в близьких освітніх умовах.

Модель дидактичного процесу - це еталонне уявлення про навчання, виховання або розвиток суб'єктів діяльності. Модель дидактичного процесу визначає цілі, основи організації та проведення навчального процесу в різноманітних навчальних закладах і може бути структурною, динамічною, факторною, функціональною і соціально-технологічною.

Характеризуючи взаємовідносини студента і викладача в межах синергетичної моделі педагогічної освіти, Г. Нестеренко [7] зазначає, що вони мають відзначатися:

- відкритістю освітнього процесу і змісту навчального матеріалу для інновацій, які можуть запропонувати не лише викладачі, а й студенти;

- переходом від переважної орієнтації на відтворювальні навчальні завдання до орієнтації на продуктивну теоретичну і практичну діяльність; 
- заміною суб'єкт-суб'єктних взаємовідносин викладача і студента на взаємини вільної співпраці заради розвитку й пізнання;

- дотриманням викладачами принципів індивідуального підходу до студентів зі спрямованістю навчально-виховної роботи на їх самоосвіту, самовиховання, самореалізацію;

- звільненням студента і викладача від стереотипів і педагогічних догм у організації й у змісті навчально-виховного процесу;

- сприянням системи вищої освіти формуванню у майбутніх фахівців відповідальності за долю всього суспільства.

На наш погляд, зазначені позиції повинні мати місце і в процесі формування методичних умінь у майбутніх учителів початкової школи.

Навчальний процес формування методичних умінь вчителів початкових класів $\epsilon$ складним системним об'єктом, детальне вивчення якого передбачає необхідність його організації з урахуванням системного підходу до всіх складників: цілей, змісту, методів, форм і засобів навчання студентів у ВНЗ. Для оптимальної організації самоосвітньої діяльності та іiі діагностики має бути виокремлення у змісті навчального матеріалу цілььового, емоційно-ціннісного, критичного, рефлексивного, творчого і регулюючого компонентів.

Успіх процесу залежить від відповідності запропонованих технологій структурі діяльності, що неможливе без застосування педагогічного моделювання. Вимоги до моделей, розроблені Д. Новіковим [8], передбачають наявність низки вимог.

Першою вимогою $\epsilon$ інгерентність, що визначає достатній ступінь погодженості створюваної моделі з середовищем (створювана модель має бути погодженою 3 освітнім середовищем, у якому вона буде функціонувати, входити до складу цього середовища як природня складова частина).

Друга вимога - простота моделі, пов'язана з процесом формалізації в моделюванні, яке полягає у виокремленні істотних якостей або характеристик моделі і нехтуванні інших, менш важливих і менш істотних.

Третя вимога - адекватність моделі, що означає можливість з їі допомогою досягнення поставленої мети педагогічної діяльності згідно з окресленими цілями. Адекватність моделі означає, що вона досить повна, точна й може бути реалізована [2]

Перш ніж приступити до моделювання процесу самоосвітньої діяльності майбутніх учителів початкової школи, доцільно було дослідити питання про те, які види моделей педагогічних систем застосовуються в педагогічних науках. Вивчення літератури 3 цього аспекту моделювання дозволило встановити, що: у теорії педагогічного проектування виокремлюють прогностичну модель для оптимального розподілу ресурсів і конкретизації цілей; концептуальну модель, засновану на інформаційній базі даних і програми дій; інструментальну модель, за допомогою якої можна підготувати засоби виконання й навчити викладачів роботі з педагогічними інструментами; модель моніторингу для створення механізмів зворотного зв'язку й способів корегування можливих відхилень від запланованих результатів; рефлексивну модель, яка створюється для вироблення розв'язку у випадку виникнення несподіваних і непередбачених ситуацій.

Найбільш поширеним типом моделей у педагогіці є структурно-функціональні моделі, в основі яких лежать істотні зв'язки і відношення між компонентами системи. У загальному випадку структурно-функціональні моделі представляють у вигляді п'яти компонентів: цільового, змістового, практичного, рефлексивно-оціночного, ціннісномотиваційного [2].

Так, О. Чуб, аналізуючи процес створення освітньої педагогічної моделі, виокремлює 
такі етапи у її побудові:

1. Діагностичний, на якому відбувається визначення фактичного, наявного рівня сформованості готовності.

2. Установочно-орієнтаційний, під час якого розкривається значимість формування відповідних знань, умінь і професійно-значимих якостей, ставляться цілі й завдання професійно-педагогічної підготовки. На цій стадії студенти ознайомлюються 3 перспективами розвитку особистісного професійного росту, відбувається їхнє первинне самовизначення щодо пропонованих програм і стратегій професійного розвитку.

3. Діяльнісно-формуючий, на якій відбувається залучення студентів до творчої виховної діяльності у межах спеціально створених педагогічних умов. Здійснення поточного контролю й керування діяльністю студентів припускає зростання їхньої активності, участь у побудові варіативного компонента навчальних програм, у виборі рольових позицій від імітатора й спостерігача до перетворювача й організатора, а також надання свободи вибору шляхів, способів і засобів здійснення навчальної й професійної діяльності.

4. Рефлексивно-оцінний, де здійснюється аналіз і рефлексія, оцінка й самооцінка ступеня засвоєння студентами творчої виховної діяльності й готовності до неї.

5. Закріплюючо-ідентифікуючий, у ході якого відбувається корекція й самокорекція набутих знань, умінь і якостей, їх закріплення, а також доповнення й зміна програми професійного розвитку студента.

6. Діагностико-контролюючий, на якому визначається рівень готовності студентів до творчої виховної діяльності, а також перевірка ефективності протікання процесу формування даної готовності [10].

Дослідниця вважає, що процес проходження стадій носить циклічний характер, де зміст і кількість циклів визначається етапами підготовки й змінами в рівнях готовності студента до творчої виховної діяльності.

Ознайомлення з теоретичними основами педагогічного моделювання дало можливість обгрунтовано підійти до розроблення моделі самоосвітньої діяльності майбутнього вчителя початкової школи.

У розробленні моделі діагностики методичних умінь майбутніх учителів початкової школи ми враховували те, що моделювання педагогічного процесу забезпечить інтелектуально-особистісний розвиток студентів за умови, якщо:

- модель передбачатиме єдність і цілісність інтелектуального, емоційного й особистісного розвитку студентів, враховуватиме основні елементи педагогічного процесу (мету освіти, іiі зміст, педагогічні технології, учасників навчальної діяльності, їх позиції і взаємини) і буде зорієнтована на інтеграцію цілей, змісту, умов і специфічних характеристик особистісно зорієнтованого навчання;

- кожний елемент моделі буде зорієнтований на іï мету, а сама мета виступатиме системоутворювальним елементом моделі;

- у змісті навчання враховуватимуться особливості інтелектуально-особистісного розвитку кожного студента, а індивідуальна траєкторія формування методичних умінь студента орієнтуватиметься на пріоритет його особистісного змісту й цінностей, різноманіття можливостей, здібностей і потреб;

- при реалізації всіх варіантів моделі враховуватиметься специфіка педагогічного процесу, забезпечуватиметься рефлексія на рівні знань, почуттів і видів діяльності кожного студента. Перевагою методики є універсальність, зручність та економічність у проведенні обстеження та обробленні результатів, гнучкість - можливість варіювати як тестовий 
матеріал (списки цінностей, мотивів), так і інструкції.

У своїх підходах до розроблення моделі діагностики методичної підготовки майбутніх учителів початкової школи ми також уважали, що модель має розкривати особливості даного феномену, відображати основні етапи його формування, фіксувати основні елементи дидактичної системи забезпечення реалізації даного процесу у практиці навчання студентів.

Відповідно, лабораторією впровадження програмних педагогічних засобів ХДУ був створений інструмент діагностики методичної компетентності студентів факультету дошкільної та початкової освіти - веб-сайт «еcology». Сайт опублікований за адресою ecology.ksu.ks.ua. Сайт розроблявся 3 використанням технології ASP.NET 2.0 та MS SQL Server 2005. (веб-сайт відкритий до доступу студентам, що пройшли авторизацію та зараховані у групу викладачем). Відповідно до структурних компонентів світогляду (діяльнісного, особистісного, когнітивного) він дає змогу аналізувати філософські, політологічні, соціальні, моральні, природничі, естетичні аспекти ставлення студентів до екологічних проблем. Закрита форма відповідей давала можливість автоматизувати процедуру підрахунку результатів і здійснити це за допомогою комп'ютера. Перевагою методики є універсальність, зручність та прозорість у проведенні обстеження та обробленні результатів. Ознайомитися з результатом тестування має можливість не тільки викладач, але і студент, результат тестування візуалізовано у вигляді діаграм, викладач має можливість змінювати зміст тестів, категорії, параметри оцюнювання. Програма легко встановлюється в декілька кроків і не потребує великого об'єму вільного місця в пам'яті комп'ютера. Системні вимоги до програмного та апаратного забезпечення:

1. Доступ до мережі Internet.

2. Наявність версій браузера (версій, які не нижче): Internet Explorer 6, Firefox 2, Google Chrome.

3. Процесор 1100Mhz, оперативна пам'ять $256 \mathrm{Mb}$.

Ураховуючи те, що сучасні студенти мають ноутбуки або персональні комп'ютери, застосування цієї програми є актуальним. Зауважимо також, що на факультеті дошкільної та початкової освіти ХДУ, де проводилося експериментальне дослідження, створені спеціальні умови для активного використання інформаційних технологій у навчальному процесі. Так, на факультеті є комп'ютерний клас, розрахований на роботу підгрупи з 12 осіб, регламентом роботи факультету передбачено час для самостійної роботи студентів у комп'ютерному класі, всі комп'ютери підключено до мережі Інтернет і до внутрішньої університетської мережі. Це також дає змогу виконувати завдання, пов'язані з їх фахом не тільки в аудиторії, а й у позаурочний час, що значно підвищує якість підготовки майбутніх спеціалістів.

Сайт має галерею та сторінку відвідувачів, де студенти можуть залишати свої враження від курсу та побажання. Комп'ютерна візуалізація навчальної інформації позитивно впливає на когнітивні процеси: стимулює увагу студентів під час виконання тестових завдань, активізує процеси мислення під час створення навчальних проектів екологічного спрямування. Застосування кольору, графіки, звуку, сучасних засобів відеотехніки дозволяє моделювати різноманітні ситуації (Рис. 1): 


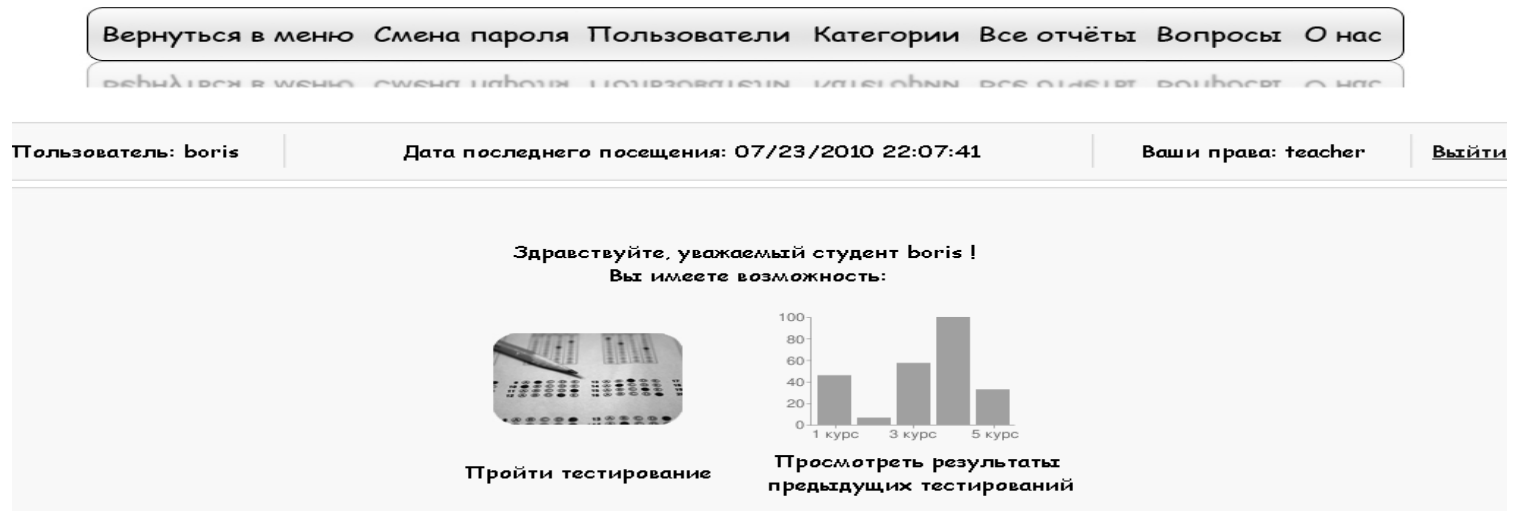

Рис. 1. Стартова сторінка програми.

Після тестування програма автоматично виконує потрібні розрахунки і демонструє графічне зображення результатів (Рис. 2):



(С Copyright 20010. Лаборатория разработки и енедрения педагогических программньтх средств НИИ ИТ ХГУ. All Rights Reserved. Version 1.1

Рис. 2. Карта розвитку показників когнітивних, мотиваційних, рефлексивних компонентів, відображена у стовпчиковій діаграмі.

У своїх підходах до розв'язання проблеми ми виходили 3 того, що можливості комп’ютера як навчального засобу пов'язані з його потенціальним впливом на різноманітні види діяльності студентів під час навчання у вищому закладі, а саме:

- здатністю впливати на результативність основних видів діяльності студентів, якість самостійної роботи, оптимізувати підготовку до аудиторної роботи, педагогічної практики та науково-дослідницької діяльності;

- стає доступним дистанційне навчання, що дає можливість студентам отримувати необхідну методичну допомогу в будь-який час і в бажаному обсязі;

- створюється оптимальне середовище для удосконалення технологічної майстерності щодо екологічного виховання дітей дошкільного віку;

- виникає можливість регулювати рівень навчальних завдань у міру ускладнення, що позитивно відображається на ефективності контролю знань на кожному етапі навчання;

- підвищується мотивація діяльності завдяки індивідуалізації навчання, можливості самостійно обирати траєкторію навчання; 
- комп'ютерна візуалізація навчальної інформації позитивно впливає на когнітивні процеси: стимулює увагу студентів під час виконання тестових завдань, активізує процеси мислення під час створення навчальних проектів екологічного спрямування. Застосування кольору, графіки, звука, сучасних засобів відеотехніки дозволяє моделювати різноманітні ситуації.

У подальших роботах розглянемо методику створення типологічних груп (за рівнем знань та спрямованістю інтересів), що дає змогу викладачам диференціювати самостійну роботу студентів, визначаючи коло питань для самостійного опрацювання.

\section{Література}

1. Бондаренко С. В. Моделювання складних системно-діяльнісних об'єктів у психолого-педагогічних дослідженнях [Електронний ресурс]/ С. В. Бондаренко.- Режим доступу: http : //roman.by/r-89699.html 2. Горячова М. В. Моделирование педагогических процессов [Электронный pecypc]/ M. В. Горячова. - Режим доступа: http: // www.rae.ru/zk/arj/2007/11/Goryachova.pdf. 3. Зязюн I. А. Краса педагогічної дії [навч. посіб.] / І. А. Зязюн, Г. М. Сагач. - Київ : Українсько-фінський інститут менеджменту i бізнесу, 1997. - 268 с. 4. Игнатова В. А. Педагогические аспекты синергетики / В. А. Игнатова // Педагогика. - 2001. - №8. - С. 26-31. 5. Кульневич С. В. Педагогика личности от концепций до технологий: [учеб.-практ. пособ. для учителей]/ С. В. Кульневич. - Ростов н/Д: Творческий центр «Учитель», 2001. - С. 106-109. 6. Маткин В. В. Ценностно-синергетический подход и его реализация в процессе педагогической подготовки будущих учителей / В. В. Маткин // Наука и школа. - 2001. № 6. - С. 10-12. 7. Нестеренко В. Г. Можливості особистості в контексті синергетичної моделі вищої освіти / В. Г. Нестеренко // Вища освіта України. - 2004. - № 1. - С. 25-34. 8. Новиков Д. А. Статистические методы в педагогических исследованиях (типовые случаи) / Д. А. Новиков. - Москва : МЗ-Пресс, 2004. - 67 с. 9. Хоружа Л. Л. У пошуках нової моделі педагогічної освіти / Л. Л. Хоружа // Вища школа. - 2009. - №11. - С. 23-31. 10. Чуб Е. В. Моделирование педагогического процесса как средство формирования ключевых компетенций будущего специалиста [Электронный ресурс] / Е. В. Чуб. - Режим доступа : http://www.conf.muh.ru/080215/thesis_Chub.htm 11. Штофф В. А. Моделирование и философия / В. А. Штофф. - Москва : Наука, 1966. - 300 с.

Аліна Бугра

\section{МОДЕЛЬ ІНДИВІДУАЛІЗАЦІЇ САМОСТІЙНОЇ НАВЧАЛЬНОЇ ДІЯЛЬНОСТІ СТУДЕНТІВ ТЕХНІЧНИХ СПЕЦІАЛЬНОСТЕЙ ВНЗ}

Бугра А. В. Модель індивідуалізації самостійної навчальної діяльності студентів технічних спеціальностей ВНЗ.

У статті обгрунтовано необхідність розв'язання проблеми індивідуалізації самостійної навчальної діяльності студентів технічних спеціальностей під час вивчення математики у вищому навчальному закладі. Автором запропоновано експериментальну модель індивідуалізації, яка містить цільовий, теоретико-методологічний, змістовий, технологічний, оцінно-результативний блоки. Методологічним підгрунтям побудови моделі визначено системний, синергетичний, особистісно зорієнтований, діяльнісний, варіативно-модельний i компетентнісний підходи.

Ключові слова: модель, моделювання, педагогічне моделювання, структура моделі, 